\title{
MIÉRT JÓ SZENTESEN ÉLNI? - EGY HAZAI KISVÁROS LAKOSSÁGÁNAK ÉLETMINŐSÉGE ÉS HELYI KÖTŐDÉSE
}

\author{
LŐRINCZ KATALIN - KŐVÁRI EDIT MÁRIA - BANÁSZ ZSUZSANNA \\ WHY IS IT GOOD TO LIVE IN SZENTES? \\ - QUALITY OF LIFE AND ATTACHMENT OF LOCAL RESIDENTS IN A SMALL TOWN
}

\begin{abstract}
Between summer 2018 and spring 2019, a study was conducted by the researchers of the University of Pannonia to examine Szentes, a small town in the Great Hungarian Plain. The study focused on the inhabitants' attachment to the town, quality of life, internal image, and the locals' satisfaction level with the settlement's factors. The survey of Szentes fits with the aspirations of the $21^{\text {st }}$-century challenges of (small) rural towns (Veszprém, Kőszeg, Gyöngyös, Zirc). These challenges include retaining the young $\mathrm{Y}$ and $\mathrm{Z}$ generations and active population; liveable settlements; and sustainable rural development. During the research some local key determining figures were cross-examined in structured interviews. In addition, data were gathered applying a focus group method along with a survey reflecting 527 local respondents' opinions. The results provide a brief summary not only of the areas in which Szentes can improve the inhabitants' quality of life and the conditions of its settlements, but also of how it can be a more attractive place to live overall.
\end{abstract}

Keywords: Szentes, small town, quality of life, local attachment, settlement conditions, settlement development

\section{Bevezetés}

Szentes helyi lakosságának kötődését, szubjektív életminôségét, a városról kialakult képét (belső imázs), valamint a települési tényezókkel való elégedettséget vizsgálta az a kutatás, melyet a Pannon Egyetem munkatársai végeztek 2018 nyara és 2019 tavasza között. Több mérőszáma is létezik az életminőségnek, azonban ezek túlnyomó részt csak országos szinten érhetők el (BANÁsz Zs. 2019). A Szentesre irányuló kutatás elsősorban arra a fontos kérdésre keresi a választ, hogy miért jó ma Magyarországon egy kisvárosban (Szentesen) élni, illetôleg milyen összefüggés mutatható ki a lakosság szubjektív életminősége (boldogság, egészség), a helyi kötődés, valamint a települési tényezőkkel való elégedettség között. Az alföldi kisvárosra irányuló felmérés szorosan illeszkedik abba a törekvésbe, mely a hazai vidéki városok (Gyöngyös, Kőszeg, Veszprém, Zirc) 21. századi kihívásait - úgymint a fiatal Y, Z generáció és aktív népesség megtartása, az élhető település, a fenntartható vidékfejlesztési irányok - mutatja be (LóRINCZ K. 2016). A szentesi felmérés eredményeinek gyakorlati felhasználása elsősorban a terület- és településfejlesztésben érintett szereplők (önkormányzat, gazdasági szereplők, beruházók, civil szervezetek) számára ad értékes és releváns információkat.

A tanulmány fő célja a Szentes településre vonatkozó életminőségi, helyi kötődési és belső imázs jellemzők vizsgálata. Kutatási kérdésein a következők voltak:

Kimutatható-e szignifikáns kapcsolat és ha igen, ez milyen erős a Szenteshez való kötődés, a települési tényezőkkel való elégedettség és a lakosok demográfiai jellemzői között?

Mely területeken szeretnék leginkább fejleszteni a kisvárost a helyiek? Ehhez kapcsolódóan nem volt előzetes feltételezésünk. 


\section{A kutatás módszertani háttere}

A primer kutatás több szempontból, kvalitatív és kvantitatív módszertant használva tárta fel az összefüggéseket. Ezzel elősegíti a településfejlesztési irányok megalapozottságát, illetőleg egy társadalmi szempontból (is) vonzó élettér kialakítását. A szerzők:

- a városban élő, betelepedett vagy visszatérő lakosokat kérdeztek fókuszcsoportos interjún keresztül;

- a város életében meghatározó, döntéshozó személyeket kérdeztek strukturált interjúk formájában;

- a helyi lakosság véleményét tárták fel egy kérdőives lakossági felmérés keretében, mely összesen 527 válaszadó véleményét tükrözi.

Az eredmények alapján röviden összegezhető, hogy Szentes város - az önkormányzat, vállalkozások, civilek munkáján keresztül - mely területeken tudja javítani a lakosok életminőségét, települési adottságait, milyen fejlesztések szükségesek a vonzó(bb) lakóhely érdekében. A tanulmány - a terjedelmi korlátok miatt - a lakossági kérdölv eredményeire koncentrál.

\section{Versenyképességi dimenziók a hazai kisvárosok esetén}

A kedvezőtlen demográfiai mutatók alapján jelenleg az az alapforgatókönyv, hogy a következő húsz évben 8,75 millióra csökken majd Magyarország népessége (KSH Népességtudományi Kutatóintézet 2019). A népességcsökkenés mértéke, intenzitása eltérő térbeli mintát mutat hazánkban: a belső migráció, az országon belüli vándorlás jelentősen befolyásolja az egyes települések pozícióját. A migrációs döntések mögött álló folyamatokat és eseményeket számos kutató vizsgálta (DövéNYi Z. 2007; HAUTZINGER Z. et al 2014; Kostanick, H. L. 2019).

A belső vándorlás és a kivándorlás jelensége általánosnak tekinthető; a hangsúly egyre inkább azon van, hogy miért maradnak helyben az emberek? Jelen tanulmány a hazai városhálózat jellegzetességeiből kiindulva a kisvárosok speciális helyzetét mutatja be, majd konkrétan Szentes városra, annak lakosságára fókuszál.

Magyarország 3155 települése közül összesen 322 minösül jogállása szerint városnak (vagyis nem a fóváros vagy kerülete - további $24 \mathrm{db}$, nem megyeszékhely - $18 \mathrm{db}$, vagy megyei jogú város - $5 \mathrm{db}$ ). Ez a magyar településállomány 10,21\%-át jelenti, ahol a magyar lakossága közel egyharmada (32,6\%-a) él (KSH 2019).

A városi jogállású településeket a népességszám alapján a KSH további öt kategóriába sorolja, többségük a 10000 fó alatti csoportba tartozik (1. ábra). Nyilvánvalóan számos olyan városi rangot nyert (városi jogállású) település tartozik ide, amely tényleges vonzáskörzettel vagy magasabb szintú szolgáltatásokkal nem rendelkezik.

A magyar városkutatások a városodás jelenségét hangsúlyozzák. ENYEDI GY.-HoRVÁTH Gy. (2002) szerint az elmúlt fél évszázadban a várossá fejlődés folyamata elenyésző volt, leginkább a nagyközségekből várossá kinevezett települések száma emelkedett. Azonban ha megnézzük a várossá nyilvánított települések számát (https://www.varossanyilvanitas. hu) láthatjuk, hogy 1970 óta összesen 271 település nyerte el a városi rangot. Az ENYEDI Gy.-HoRvÁTH Gy. (2002) által szerkesztett könyv megjelenése után 94 települést, 2010 után pedig csak 2013-ban nyilvánítottak várossá 18 települést.

A városok funkcionális és hierarchikus típusainak meghatározásával több magyar szerző (FARAGó L. 2007, PIRISI G. 2009, JENEY L. 2013) is foglalkozott. A hazai városok 


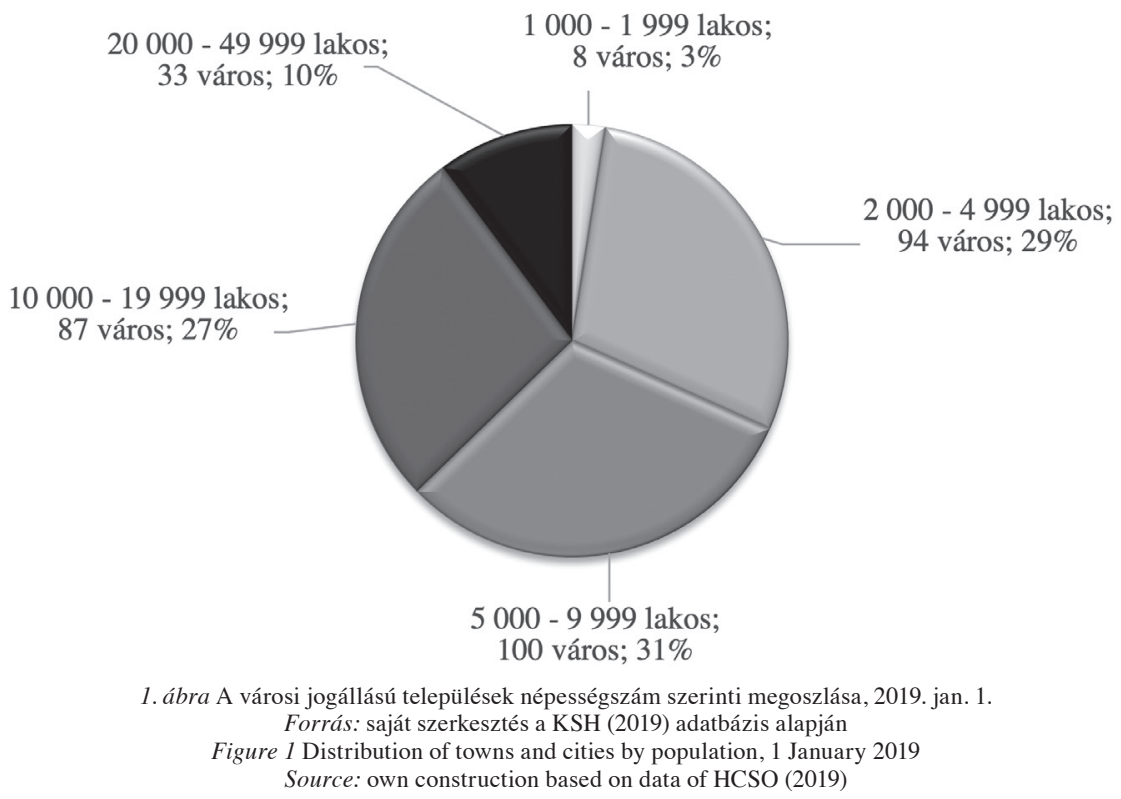

településhierarchiában betöltött szerepe magára a városi hierarchiára, valamint a központi funkciók szintjére, az intézmények meglétére utal. Az ún. városi jogállású települések lehetnek közép- vagy kisvárosok, illetőleg városias jellegú települések. A tanulmányban vizsgált Szentes a kisvárosi kategóriába tartozik. Az Alföld területére vonatkozóan foglalkoztak a települések lehatárolható vonzáskörzetével - ezek alapján Szentes 4 települést vonzó, a 18-36000 fős népességgel rendelkező körzetbe (vonzásterület kategóriába) tartozó tradicionális mezóváros (KISS J. P.-BAJMÓCY P. 2001).

A településtípusok befolyásolhatják az ott élőknek a telepuilés iránti bizalmát (BoDOR Á. et al. 2017),) biztonságérzetét (DuSEK T. 2015), a helyi gazdaságfejlesztés fontosságát (RAPKAY B. et al., 2013), a település versenyképességét (KolTAI Z. 2015). Világszerte jelentôs problémát jelent a kisvárosok elnéptelenedése, a lakosok nagyvárosba történó elköltözése (Peters, D. J. 2019), legyen szó akár Európáról (HAMdouch, A. I. et al. 2017; SMITH, I. 2017), akár Japánról, vagy Németországról (WIRTHA, P. et al. 2016).

Széles szakirodalma van az olyan kutatásoknak, amelyek különböző településtípusok szerint, vagy kifejezetten kisvárosokra vonatkozóan végeznek vizsgálatokat, nemcsak demográfiai megközelítésből, hanem életminőség, társadalmi attitúd, vagy társadalmi tôke szempontból is. Nemzetközi szintú elemzések elérhetôk például Kanada kisvárosairól (EveritT, J. C. - Gill, A. M. 1993), Franciaország és Lengyelország kisvárosi életminőségének összehasonlításáról (KwIATEK-SolTYs, A.-MAINET, H. 2014). Magyarországon is foglalkoztak a szubjektív életminőség térbeli vonatkozásaival országos szinten (KéKESI M.Z. 2007, IvONYI É. 2017) és települési szinten is. Utóbbira példa a Kreatív város - fenntartható vidék (KRAFT) program keretében felmért városokról szóló jelentések, nevezetesen Veszprémről (GAÁL Z. et al. 2019), Kőszegről (LőRINCZ K. 2016), Murafölde (Nagykanizsa és környéke) településeiről (SzABó M. et al. 2019). Az elmúlt évtizedben több településen is végeztek életminőséggel összefüggó kutatásokat, például Budapestről és a vidéki nagyvárosok helyzetéről (EGEDY T. 2009), Gyöngyösről (LŐRINCZ K. 2019), vagy Zircrôl (LÔRINCZ K.-RAFFAY Á. 2017). 


\section{Szentes és a Szentesi járás pozíciója a Dél-alföldi térségben: népesség és jövedelem}

Szentes város a Dél-alföldi régióban, Csongrád megye északi részén, a Tisza bal partján található. A Szentesi járás központja, a megye 3. legnagyobb népességú városa (Szeged és Hódmezővásárhely után). 2019. január 1-ján a város lakónépességének száma 26887 fő volt, a lakások száma pedig 12692 volt (KSH 2020). Szentes tipikus kisváros, járási székhely, alföldi mezőváros, amelynek kiterjedt térkapcsolatai vannak. Ezek többnyire járási szintúek, illetve a szomszédos városokkal vannak összefüggésben, de jónéhány olyan speciális funkció is jellemzi a várost, amelyek tekintetében akár regionális szintú szerepkörrôl (pl. gimnázium múködtetése) is beszélhetünk.

A város Budapesttôl 137 km-re, Szegedtől 62 km-re fekszik. A legközelebbi város Csongrád $(12 \mathrm{~km})$. Hódmezóvásárhely 25 km-re, Szarvas 36 km-re fekszik tőle. Térben leginkább a Kecskemét-Békéscsaba fejlődési tengelyhez áll közel, de a szakemberek szerint ennek valós fejlődési potenciálját a tervezett M44 gyorsforgalmi út megépítése fogja megadni (Szentes város Integrált Településfejlesztési Stratégiája 2014).

A Központi Statisztikai Hivatal (2015) szerint hat eltérô település-hierarchia szintet különböztetünk meg. A központi szerepkör mértéke, a városi funkciók alapján a városi települések négy (főváros, felsőfokú-, középfokú- és alsófokú központ) csoportba sorolhatók. Csongrád megyében a felsoroltak közül mindhárom városi szint jelen van a településállományban: Szeged mint felsőfokú központ (162 ezer lakos), Hódmezővásárhely mint középfokú központ (45 ezer lakos), illetve a területen rajtuk kívül még 8 alsófokú központ - köztük Szentes - található.

A statisztika területi alapon lehetővé teszi az egyes járások összehasonlítását. Csongrád megye 6 járásra osztható, melyek központjai eltérő népességszámmal rendelkeznek. A népesség kormegoszlása a járási székhelyek esetén meglehetősen homogén (KSH 2018): A szentesi járásban az időskorúak aránya (22\%) jóval meghaladja a 0-14 éves fiatal népesség arányát (14\%). A munkaképes (15-64 éves) korosztály aránya mind a szegedi, mind pedig a hódmezővásárhelyi járásban magasabb értéket mutat (2.ábra).

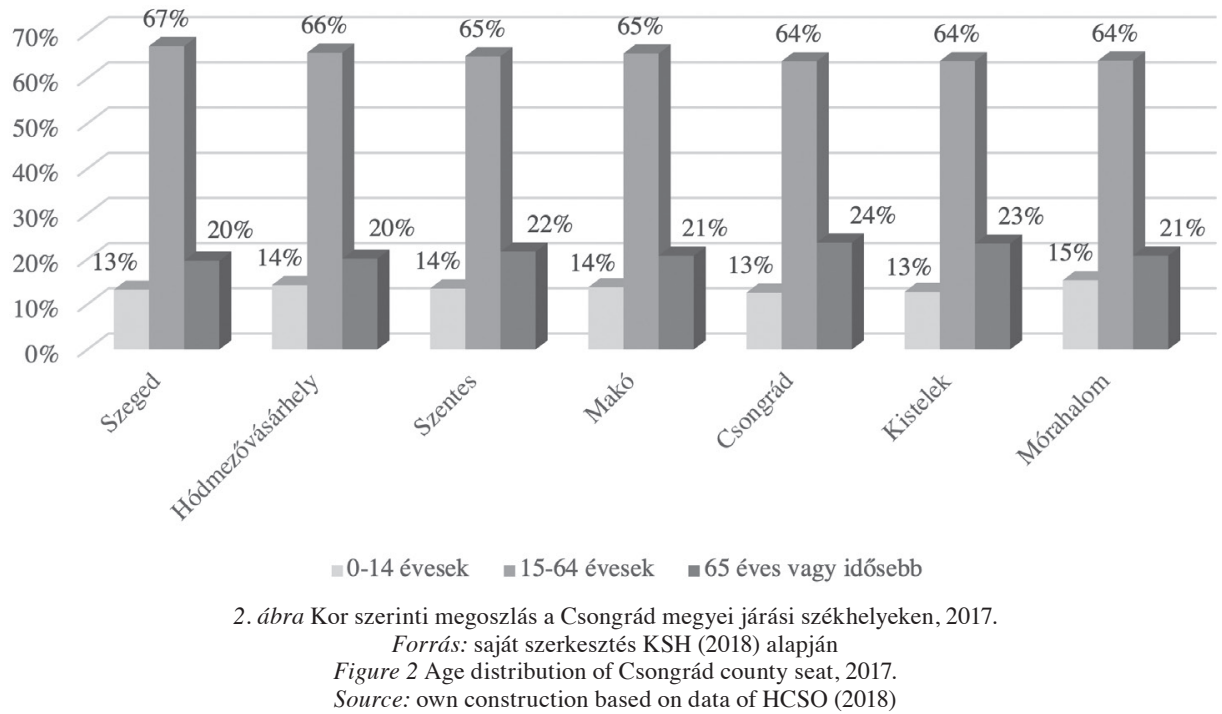


A 2009-2019-es időszakot vizsgálva elmondhatjuk, hogy a szentesi járás népessége fogy. Míg 2009. január 1-jén 29117 fó élt Szentesen, 10 évvel később már csak 26887 fó (KSH 2020). A népesség közel 8\%-kal csökkent. Ennek oka a csökkenő gyereklétszám mellett az elvándorlás volt. A 3.ábra mutatja Csongrád megye járási székhelyeinek oda- és elvándorlását 2017-ben, ezer lakosra vetítve. Szentes azok közé tartozik, ahonnan inkább elvándoroltak, mint odaköltöztek volna. A negatív egyenlegú járások közül a Szentesi járásban volt e negatív egyenleg a legnagyobb.

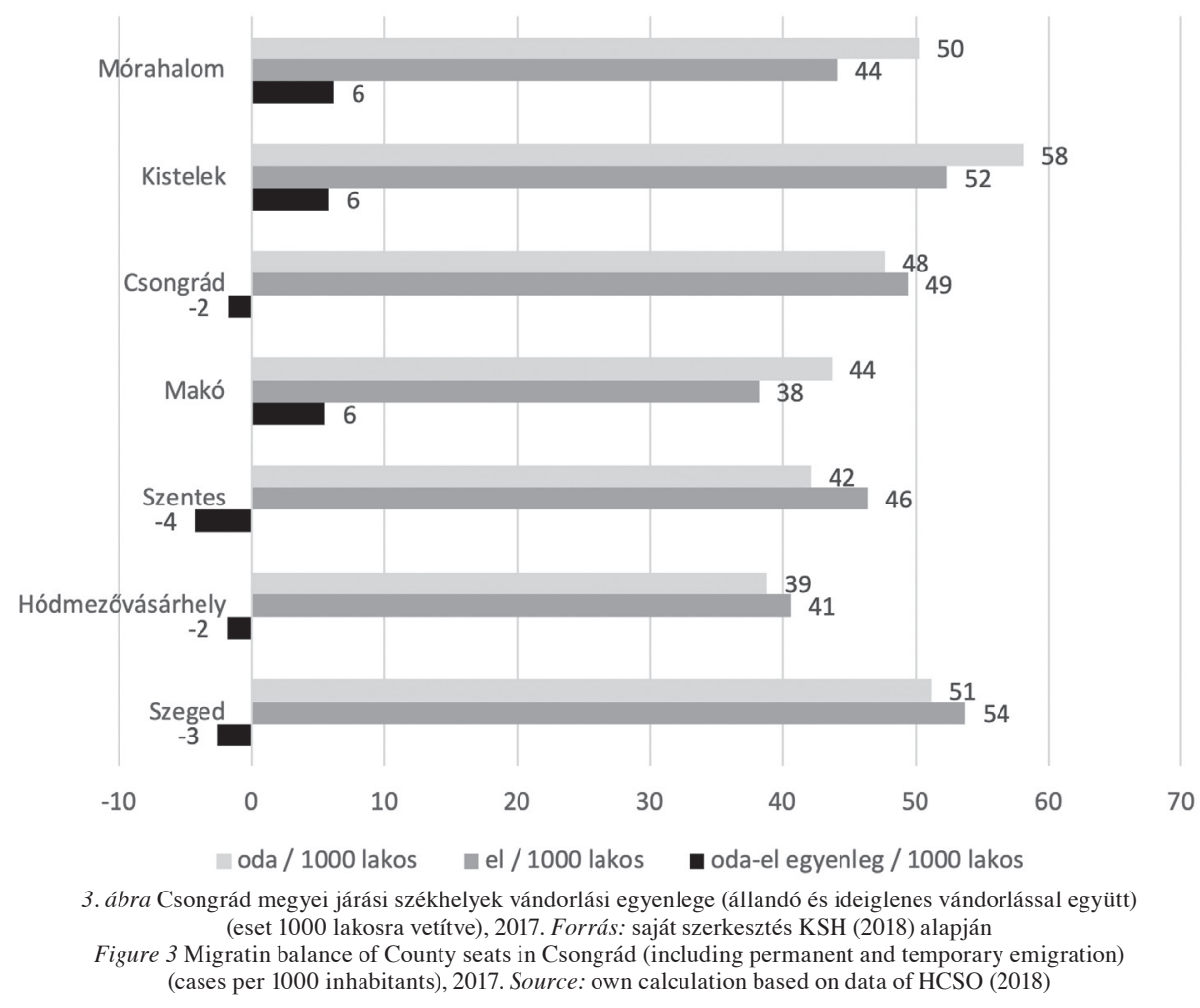

Szentes város - és a járás - demográfiai mutatói sajnos megyei szinten is kedvezőtlenek és nem jó irányúak. Az idős, egyedülálló népesség létszáma magas és nő, a fiatal népesség létszámában és arányaiban is csökken. A természetes szaporodás és a vándorlási egyenleg évtizedek óta negatív. Szentes város Integrált Településfejlesztési Stratégiája (2014) is hangsúlyozza a népességszám nagyarányú fogyását: a város 8,97\% -át vesztette el népességének tizenegy év alatt, aminél a térségben elhelyezkedő városok esetén csak Csongrád település mutatott még rosszabb értéket. Különösen fájdalmas a magasabb végzettségüek és a fiatalok elvándorlása, ami szinte kizárólag a munkalehetôségek hiányára és az alacsony bérszintre vezethetô vissza. Egyébiránt a a város iránti kötődés meglenne a helyi népességben. Bár a helyi lakosság képzettségi szintje átlagosnak mondható, az mégis csak részben szolgál bázisul a helyi gazdaságnak. A munkanélküliség nem kiugróan magas, a foglalkoztatás rátája pedig viszonylag magas.

Kihívást jelent a hazai kisebb lélekszámú települések számára a globális gazdasághoz való kapcsolódás. ENYEDI Gy. (2000, 2003) és ENYEDI GY.-HoRVÁTH Gy. (2002) szerint a magyarországi térségek (és bennük a települések) globális gazdasághoz történő kötő- 
désének foka leginkább a nagytérségi elhelyezkedéstől és a területi összetartozástól függ. Ugyanakkor a szakemberek arra is rámutattak, hogy a globális gazdasághoz való kötődés egyre inkább függetlenedni látszik például a területi-települési jellegtől, a népességszámtól, a funkcióktól, a településhierarchiában elfoglalt helytől vagy a korábbi időszakokra jellemző fejlődési dinamikától (MolnÁR B. 2006).

A hazai városhálózatot és a benne elhelyezkedő települések adaptáció orientált környezetét vizsgálta RECHNITZER J. (2002). Eredményei szerint az Alföldön - a tradicionális, regionális funkciókkal rendelkező nagyközpontok Kecskemét és Szeged vonulata mellett felismerhető már egy azonos megújítási jegyeket mutató városhalmaz is, amelynek tagjai Kiskőrös, Kiskunfélegyháza, Csongrád, Szentes, Hódmezővásárhely és Makó. Szentes város - a hivatkozott tanulmány alapján - a „készülők és a felzárkózók” csoportba sorolható.

Az egyes járások vándorlási egyenlege és jövedelemtermelő képessége között is nagy különbségeket találunk. Ebből a szempontból Szentes járás pozíciója stabilnak mondható, az egy lakosra vetített nettó jövedelem alapján a Szegedi járással egyforma besorolású (TEIR 2019). A Szentesi járásban (a 4. ábrán feketével jelölve a járás határai) 2017-ben egy lakosnak átlagosan 926023 forint éves (77 168 Ft havi) nettó jövedelme volt.

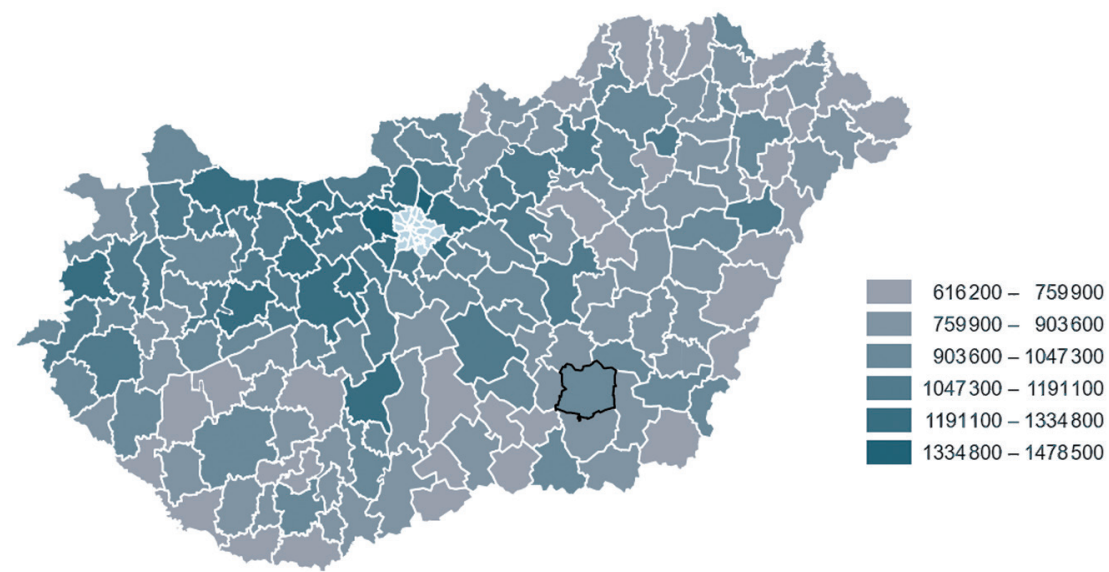

4. ábra Összes nettó jövedelem egy lakosra Magyarországon, járási bontásban (Ft/év), 2017. Forrás: TEIR (2019) Figure 4 Total net income per capita in Hungary by region (HUF/year), 2017. Source: TEIR (2019)

\section{Szentes helyzete a területi versenyben}

A települések közötti verseny a szúkös javak, erőforrások iránti rivalizálásként írható le (PoREISZ V. 2014). A területi verseny többek között a befektetésért, a népességvonzásért, a forrásokért zajlik. Jelen tanulmány egyik kiindulási pontjának tekinthető a regionális versenyképesség tényezőit és célrendszerét bemutató ún. „piramismodell” (LENGYEL I. 2010), amely a kisvárosokra is adaptálható. Egyrészt az alaptényezók (gazdasági- és társadalmi szerkezet, innovációs kultúra, döntési központok, regionális elérhetőség, környezet minősége, munkaerő felkészültsége, a régió társadalmi kohéziója) megléte, másrészt pedig a sikerességi faktorok szoros összefüggésben állnak, ezáltal is támogatják a települési versenyképességet. A „régiók, térségek és városok versenyképességének piramismodelljében” a regionális versenyképesség központi kategóriája a jövedelem, amely a régió gazdasági növekedését méri. A modellben leírt munkatermelékenység és foglalkoztatottság közvetlenül hat a lakosság életminóségére is. 
A kisvárosokra vonatkoztatva az agglomerációs előnyök kevésbé hangsúlyosak, inkább egy-két gyár vagy nagyobb cég jellemző, melyek fóként a kedvezóbb ingatlanárakat és az olc só munkaerôt használják ki. Az iparágak koncentrációja (mezőgazdaság, kézmúves jellegú élelmiszergyártás és iparmúvészeti termékek) mellett - a sikeresség szempontjából meghatározó a rátermett, megfelelóen képzett városvezetés (LENGYEL I.-RECHNITZER J. 2004). Szentes településre jellemző, hogy a helyi nagyobb vállalkozások - elsősorban a Hungerit Zrt. - foglalkoztatói szerepköre kiterjed a szomszédos megyékre (Szentes város Integrált Településfejlesztési Stratégiája 2014). A foglalkoztatás tekintetében jelentős regionális vonzáskörzettel bír a szentesi katonaság és a kórház. Amennyiben az oktatási kínálatot vizsgáljuk, úgy kiemelkedő a Horváth Mihály Gimnázium ismertsége, mely múvészeti képzése (drámatagozat) révén ismert. Szentes nagy tradíciókkal bíró sportturizmusa (vízilabda) szintén a közigazgatási határokon túlmutató jelentőségú.

\section{Adatok és módszertan}

A tanulmány Szentes településhierarchiában betöltött szerepét (település mérete, funkciói) a releváns hazai és nemzetközi szakirodalom feldolgozásával, valamint a Központi Statisztikai Hivatal adatbázisának (2000-2017 közötti vándorlási különbözet, népesség, kormegoszlás) szűrésével végeztük el. A Szentes lakosságára vonatkozó, elsôsorban kötődést és életminőséget vizsgáló adatok primer forrásból származnak. A Szentesen élőket online és papír alapú kérdőíves felmérés keretében vizsgáltuk 2018 nyara és 2019 tavasza között, így összesen 527 fós értékelhető mintát kaptunk.

Kutatási modellünkben a kérdőív alább felsorolt kérdéseire adott válaszokat tekintjük magyarázni kívánt változóknak (B), illetve potenciális magyarázó változóknak (A). Kerestük, hogy kimutathatók-e szignifikáns kapcsolatok a két kategória (A és B) között és ha igen, ez milyen erős?

B) magyarázni kívánt változók:

Mennyire kötődik Szenteshez? (1-4)

Mennyire elégedett a felsorolt 28 települési tényezővel? (1-5)

A szentesi és környékbeli hírekről/eseményekről való tájékozódásban használja-e a felsorolt 20 hírforrást? (igen/nem)

Melyik általános iskolát / gimnáziumot vagy szakközépiskolát tartja a legerősebbnek?

Milyen iparág hiányzik Ö̉n szerint Szentesen? (pl. élelmiszeripar/energetika)

Milyen vendéglátó egység hiányzik Ön szerint Szentesen? (pl. bisztró/falatozó/borház)

A nyílt kérdések a következők:

- Mi jut eszébe Szentes nevének hallatán?

- Mivel érvelne egy jövőbeni lakosnak, miért jó Szentesen élni?

- Milyen konkrét látnivalókat, rendezvényeket, fesztiválokat ajánlana Szentesen egy turistának?

- Milyen fejlesztéseket javasolna Szentesen?

A) potenciális magyarázó változók:

Milyen módon kötődik Szenteshez? (pl. itt él/dolgozik/tanul)

Mennyi éve él Szentesen ill. környékén?

Miért ezt a térséget választotta lakóhelyéül? (pl. itt született/tetszik a környék)

Nem (férfi / nő)

Életkor

Háztartás létszáma

Háztartásban van-e adott életkorú gyermek vagy eltartott? (igen/nem) 


\section{Végzettség}

Foglalkozás (pl. tanuló/fizikai alkalmazott)

Melyik gazdasági ágban dolgozik? (pl. ipar/mezőgazdaság)

Mennyire érzi magát boldognak? (1-10) Milyennek ítéli meg az egészségi állapotát? $(1-10)$

A következő fejezetben először az egyes kérdésekre adott válaszokat leíró statisztikákat összegezzük, majd az egyes kérdésekre adott válaszok közti kapcsolatvizsgálatok eredményeit ismertetjük. Mivel a kérdőívben nem szerepeltek magas mérési szintű változók, így az alábbi kapcsolatvizsgálatok elvégzésére kerül sor (eredményeiket 5\%-os szignifikancia-szinten értelmezve):

- a sorrendi skálán mérhető változók közti kapcsolat erősségének feltárására a Spearman-féle rangkorrelációs együtthatót (Rho) használjuk $(\rho)$;

- a nominális skálán mérhető változók közti, valamint a sorrendi és nominális skálán mérhető változók közti kapcsolat erősségének megállapítására a Cramer-mutatót (C);

A $\rho$ mutató a $[-1,1]$ intervallumon vehet fel értéket, a $C$ mutató a $[0,1]$ intervallumban. A vizsgált indikátorok közti kapcsolat pozitív vagy negatív volta (az indikátorok azonos vagy ellentétes irányban való mozgása) csak a $\rho$ mutató esetében értelmezhető, annak előjele alapján. A kapcsolat erôsségét mindhárom mutató esetében annak abszolút értéke adja meg, amelyet az alábbiak szerint értelmezzük: 0,4 alatti érték esetén gyenge kapcsolatról beszélünk, 0,7 felett erős, e két szám között pedig közepesen erős akapcsolat.

\section{A lakossági felmérés eredményei}

Elemzéseink közül először az egyes kérdésekre adott válaszok leíró statisztikáit foglaljuk össze, majd a kérdésekre adott válaszok közti kapcsolatvizsgálatok eredményeit.

\section{Szentes lakosságának jellemzói a kérdőíves felmérés alapján}

Először a potenciális magyarázó változók leíró statisztikáit mutatjuk be (mely kérdések mindegyike zárt kérdés volt), majd a nyílt kérdésekre (belső imázs, fejlesztési javaslatok) adott válaszokat összegezzük. A kérdőívet kitöltőknek Szenteshez való kötődését foglalja össze az 1. táblázat. Akik válaszoltak, közülük a legtöbben (312 fő) e településen élnek és dolgoznak, ôket követték az itt élő nyugdíjasok (71fő), majd azok, akik itt élnek, de más magyar településen dolgoznak (43 fó).

Milyen módon kötődik Szenteshez?

1. táblázat-Table 1 How do you relate to Szentes?

\begin{tabular}{|c|c|c|c|c|c|c|}
\hline \multirow{2}{*}{$\frac{\text { itt él }}{\mathrm{x}}$} & \multicolumn{3}{|c|}{ Szenteshez való kötődés fajtája } & fó & \multicolumn{2}{|c|}{$\begin{array}{l}\text { Megoszlások, ha a kérdésre } \\
\text { nem válaszolókat } \\
\text { is figyelembe nem vesszük } \\
\text { vesszük }(\%) \text { figyelembe }(\%)\end{array}$} \\
\hline & $\mathrm{x}$ & & & 312 & 59,2 & 59,8 \\
\hline $\mathrm{x}$ & & & Nyugdíjas & 71 & 13,5 & 13,6 \\
\hline $\mathrm{x}$ & & & $\begin{array}{l}\text { de Magyarország más } \\
\text { településén dolgozik }\end{array}$ & 43 & 8,2 & 8,2 \\
\hline $\mathrm{x}$ & & $\mathrm{x}$ & & 25 & 4,7 & 4,8 \\
\hline
\end{tabular}




\begin{tabular}{|c|c|c|c|c|c|c|}
\hline \multirow[t]{2}{*}{ itt él } & \multicolumn{3}{|c|}{ Szenteshez való kötődés fajtája } & fó & \multicolumn{2}{|c|}{$\begin{array}{c}\text { Megoszlások, ha a kérdésre } \\
\text { nem válaszolókat }\end{array}$} \\
\hline & $\mathrm{X}$ & & & 21 & 4,0 & 4,0 \\
\hline $\mathrm{x}$ & & & $\begin{array}{l}\text { kismama / gyerek(ek)- } \\
\text { kel otthon van }\end{array}$ & 15 & 2,8 & 2,9 \\
\hline $\mathrm{x}$ & & & jelenleg álláskereső & 11 & 2,1 & 2,1 \\
\hline & & $\mathrm{x}$ & $\begin{array}{l}\text { de bejárok } \\
\text { / kollégista vagyok }\end{array}$ & 2 & 0,4 & 0,4 \\
\hline & & & Egyéb & 22 & 4,2 & 4,2 \\
\hline & & & Nem válaszolt & 5 & 0,9 & - \\
\hline$\sum$ & & & & 527 & 100,0 & 100,0 \\
\hline
\end{tabular}

Forrás/Source: saját kutatás/own reserach

Arra a kérdésre adott válaszokat, hogy mióta élnek a településen, az 5. ábra foglalja össze. Azt látni, hogy túlnyomó többségében (91\%-ban) olyan emberek kerültek a mintába, akik több mint 10 éve élnek a településen, azaz már átlátják a település előnyeit, hátrányait és feltételezhetjük, hogy a Szentesen fejlesztendő területekről is határozott véleményük van.

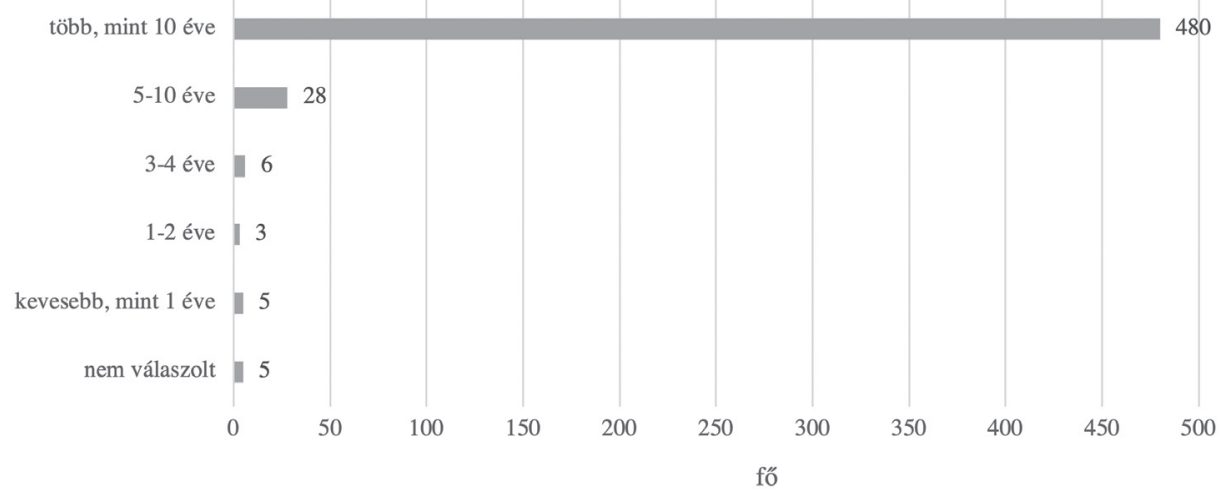

5. ábra Mióta él Szentesen, illetve környékén? Forrás: saját kutatás

Figure 5 How long have you been living in Szentes or in the surroundings? Source: own research

A tanulmány egyik fontos kutatási iránya a településválasztás oka, azaz hogy miért ezt a térséget választották lakóhelyül. A válaszadók túlnyomó többsége (70\%) születése óta Szentesen él, a második leggyakrabban említett okként (11\%) pedig az szerepel, hogy azért költözött Szentesre, mert a párja idevalósi (6. ábra).

A kérdésre értékelhetô választ adók körülbelül 1/3-a (31,9\%) férfi volt, 2/3-a (63\%) pedig nő. Ha csak azokat vizsgáljuk, akik megadták a nemüket, még közelebb kerülünk az 1/3-2/3 arányhoz (férfiak 33,6\%, nők 66,4\%). Életkorukat tekintve a válaszadók többsége a 25-44, illetve a 45-64 éves korosztályból került ki (7. ábra).

A válaszadók tipikusan 2-4 fös háztartásban élnek. A 2. táblázatban csak azokra fókuszálunk, akik jelezték, hogy háztartásukban van gyermek vagy eltartott. Összesen 341 esetben (a minta körülbelül 65\%-ában) jelölték meg, hogy legalább egy életkorcsoportban van 
a háztartásukban gyermek vagy eltartott. (Ha egy háztartásban 4 eltartott volt, a vizsgált életkorcsoportok mindegyében 1, akkor ez az egy háztartás 4 említést jelentett a 341-ből.)

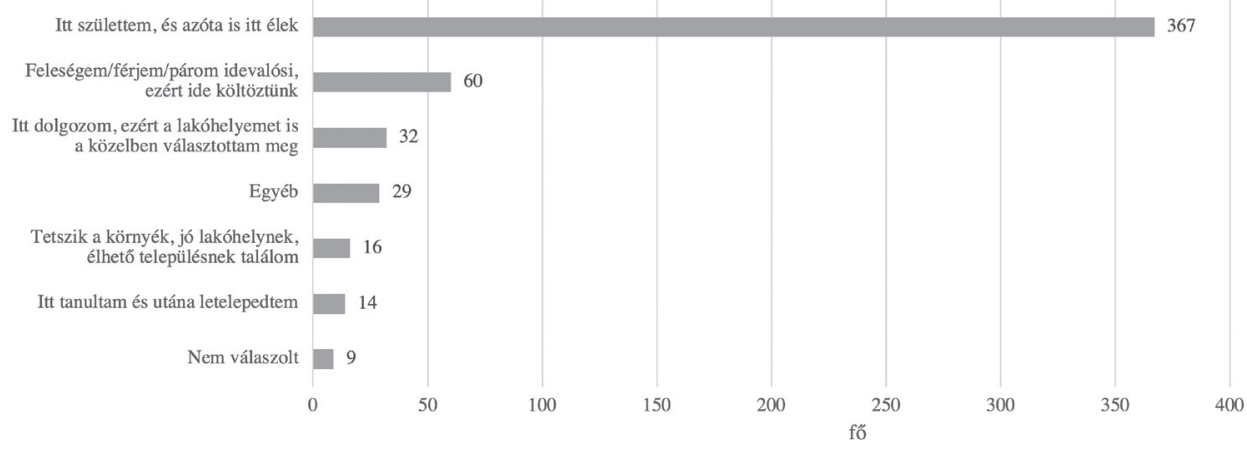

6. ábra Miért ezt a térséget választotta lakóhelyéül? Forrás: saját kutatás

Figure 6 Why did you choose this area for your residence? Source: own research

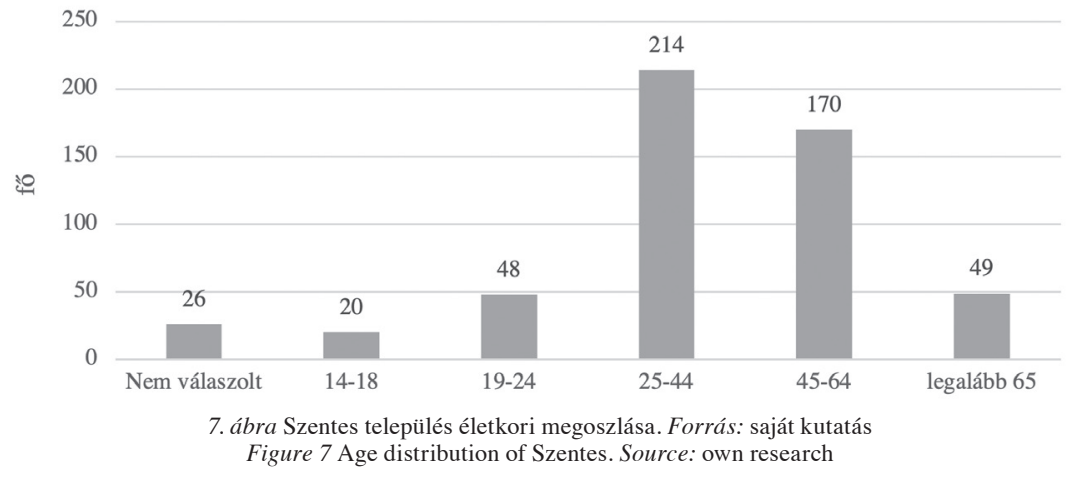

2. táblázat-Table 2

Háztartásában van gyermek vagy eltartott?

Do you have a child or dependent in your household?

\begin{tabular}{ccc}
\hline $\begin{array}{c}\text { gyermek / eltartott } \\
\text { életkora (év) }\end{array}$ & $\begin{array}{c}\text { érintett háztartások } \\
\text { száma (fó) }\end{array}$ & $\begin{array}{c}\text { Az 527 fós mintának } \\
\text { mekkora része? (\%) }\end{array}$ \\
\hline $0-6$ & 96 & 18,2 \\
$7-14$ & 94 & 17,8 \\
$15-18$ & 68 & 12,9 \\
$19-25$ & 83 & 15,7 \\
$\Sigma$ & 341 & 64,7 \\
\hline
\end{tabular}

Forrás/Source: saját kutatás/own reserach

Végzettségüket tekintve a minta kb. 45\%-a felsőfokú, 48\%-a középfokú, $7 \%$ pedig csak alapfokú (8 általános) végzettséggel rendelkezett.

Foglalkozásuk szerint a legnagyobb réteget (kb. 31\%) a szellemi alkalmazottak képviselték a mintában, majd a fizikai alkalmazottak (kb. 14\%) és a nyugdíjasok (kb. 13\%) következtek. 
Gazdasági ágazat alapján a legtöbben a közszférában dolgoznak (kb. 28\%) vagy inaktívak, például nyugdíjasok, tanulók, GYED-en vagy GYES-en vannak (kb. 21\%), a minta legkisebb része (kb. 3\%) a mezőgazdaságban dolgozik.

A 8. ábra azt mutatja, hogy egy 1-tôl 10-ig tartó skálán mennyire érzik magukat boldognak (10 jelentette azt, hogy tökéletesen boldogok), illetve milyennek ítélik meg a saját egészségi állapotukat (a 10 jelentette azt, hogy kiválónak érzik az egészségüket). Az összes válasz átlagértéke megközelítette a 7-et, mintegy 2 pontos szórással. A válaszadók inkább érzik egészségesnek magukat, mint boldognak: leginkább 8-asra értékelték a boldogságszintjüket és 9-esre az egészségi állapotukat.

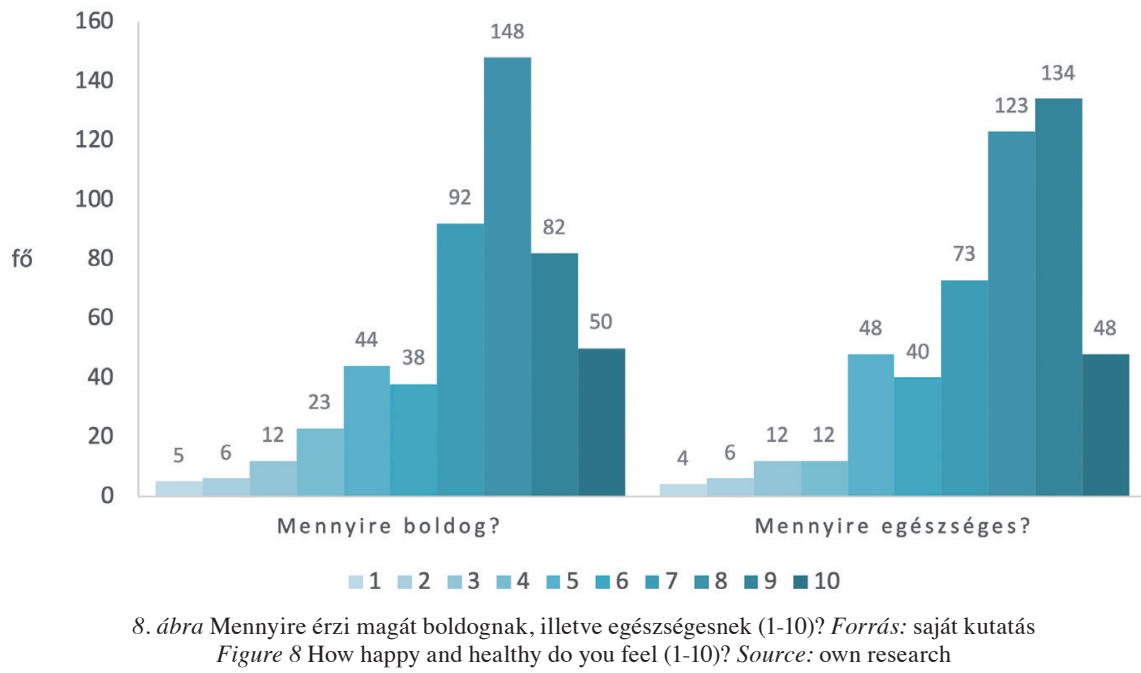

A potenciális magyarázó változók közül az alábbi demográfiai indikátorok reprezentativitását vizsgáltuk meg a Szentesről elérhető települési statisztikák (KSH 2020) alapján: nem, életkor, háztartás létszáma (ebből az eltartottak száma), végzettség, foglalkozás, foglalkozás gazdasági ágazata. A minta végzettségre és háztartásnagyságára vonatkozó reprezentativitása nem vizsgálható:

- a végzettség esetében ennek az az oka, hogy a KSH települési szinten nem teszi ezt közzé, csak a munkanélküliek esetében (a legkisebb területi egység, amelyre elérhetô a teljes lakosság végzettség szerinti megoszlása, az a járási szint);

- a háztartások összetétele és a foglalkozással kapcsolatos jellemzők esetében sem érhetők el települési adatok. A 2016-os mikrocenzus felmérés eredményeiben a megyei szint a legkisebb, amelyre elérhetők ezek az információk.

A fenti okok miatt a jelen kutatásban vizsgált mintának a nemekre és életkorra vonatkozó reprezentativitást tudtuk csak számszerúsíteni. A férfiak és a nők aránya a mintában körülbelül 1/3-2/3 volt, míg a 2018-as sokaságban körülbelül fele-fele arányban voltak a nők (53\%) és a férfiak (47\%). Az életkornál a kérdőívben más korcsoportokat használtunk, mint a KSH besorolása, ezért csak az alábbi három életkor kategória reprezentativitása vizsgálható: 14-18 éves, 19-64 éves, illetve a legalább 65 éves korosztály. E három korosztály aránya a mintánkban 4\%,82\% és 9\% volt (a maradék 5\% nem adta meg az életkorát), míg a tényleges, KSH által publikált 2018-as sokaságban: 5\%,71\%,24\%. Mindezek alapján elmondhatjuk, hogy a szentesi felmérésben alulreprezentáltak a férfiak, továbbá a 14-18 év közöttiek és a 65 év fölöttiek. 


\section{A magyarázandó változók leíró statisztikái}

A Szenteshez való kötődésük erősségét egy 1-tôl 4-ig tartó Likert skálán értékelhették a kérdőívet kitöltők, ahol 1 jelentette azt, hogy egyáltalán nem kötődik a településhez, 4 pedig azt, hogy nagyon kötődik hozzá. Nem volt olyan érték az 1-4 skálán, amelyet ne jelöltek volna. A 9. ábra mutatja a különböző erősségú (1-4) kötődés megoszlását.

Több város felmérésében szerepelt ugyanez a kérdés, ugyanúgy e négyfokozatú skálán értékelhető módon. A 3. táblázat hasonlítja össze az átlagos válaszokat.

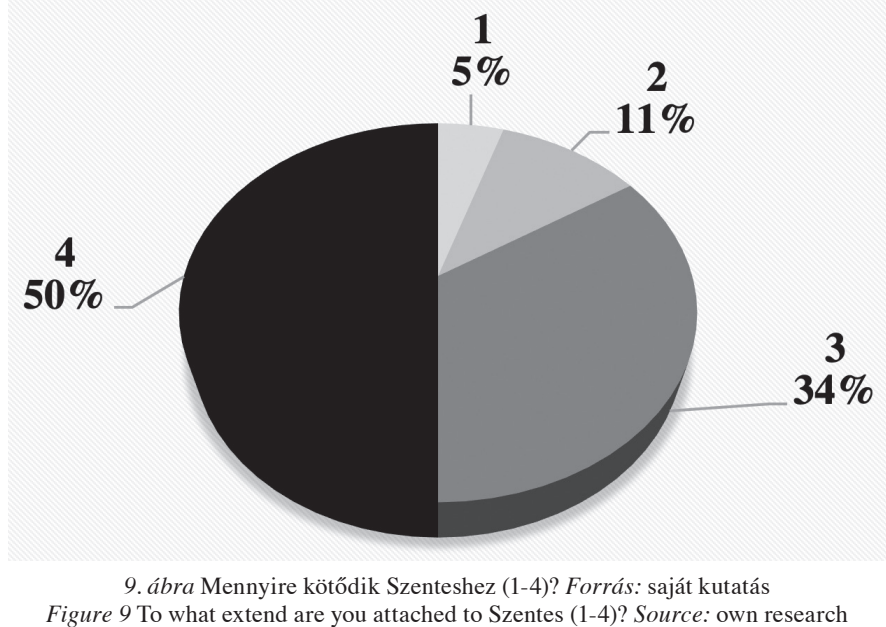

3. táblázat-Table 3

Mennyire kötődik a településhez? (1-4)

To what extend are you attached to your settlement? (1-4)

\begin{tabular}{|c|c|c|c|c|}
\hline Település megnevezése & Éve & $\begin{array}{l}\text { Elem- } \\
\text { száma }\end{array}$ & $\begin{array}{c}\text { Mennyire kötó- } \\
\text { dik a település- } \\
\text { hez? (1-4) }\end{array}$ & Hivatkozás \\
\hline Szentes & $2018-9$ & 527 & 3,29 & jelen tanulmány \\
\hline $\begin{array}{ll}\text { Mura- } & \text { központja, } \\
\text { földe } & \text { Nagykanizsa }\end{array}$ & 2018 & 800 & 3,42 & (SzAвó M. et al. 2019) \\
\hline többi települése & & 1100 & 3,27 & \\
\hline Veszprém & 2017 & 1200 & 3,54 & (GAÁL Z. et al. 2019) \\
\hline Gyöngyös & 2017 & 812 & 3,31 & (LőRINCZ K. 2019) \\
\hline
\end{tabular}

Forrás: saját kutatás, SZABó M. et al. 2019, GAÁL Z. et al. 2019, LőRINCZ K. 2019 Source: own reserach, SzABó M. et al. 2019, GAÁL Z. et al. 2019, LŐRINCZ K. 2019

Értékelhették továbbá 28 különböző települési adottsággal, tényezővel való elégedettségüket, egy 1-tôl 5-ig tartó skálán, ahol 1 jelentett azt, hogy egyáltalán nem elégedett, 5 pedig azt, hogy nagyon elégedett. Nem volt olyan érték az 1-5 skálán, amelyet ne jelöltek volna. A 10. ábra mutatja az egyes városi tényezőkkel való elégedettség átlagát. A legkevésbé elégedettek a válaszadók a szórakozási lehetóségekkel, az éjszakai élet kínálatával, 
Település természeti adottságai

Megközelíthetőség

Közintézményekkel való ellátottság

Település történelme, hagyományok, tradíciók

Nyugalom

Oktatási intézmények számossága

Kerékpárút megléte

Infrastruktúra (pl. gáz, víz, csatornázottság, utak állapota, közvilágítás)

Közbiztonság színvonala

Vásárlási lehetôségek

Pihenés, feltöltôdés lehetôségei (wellness, amatôr sport, strand) Lakókörnyezet állapota (pl. zöldterületek, tisztaság, rendezettség)

Emberi (családi, baráti) kapcsolatok, közösségek megléte

Oktatás színvonala

Járda megléte

Lakosság barátságossága

Éttermek vendéglátás színvonala

Látnivalók száma színvonala

Folyamatos fejlesztések a településen

Kulturális programok választéka

Megélhetési költségek

Parkolási lehetőségek

Lakosság korösszetétele

Egészségügyi ellátás, - szolgáltatások

Munkalehetőségek

Helyi tömegközlekedés

Kedvező ingatlanárak

Szórakozási lehetőségek, éjszakai élet
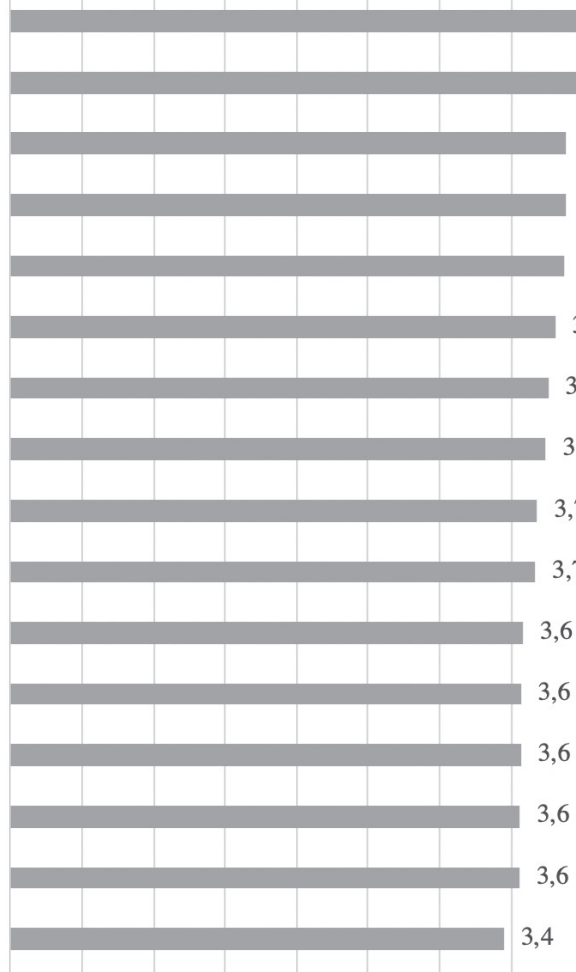

3,4
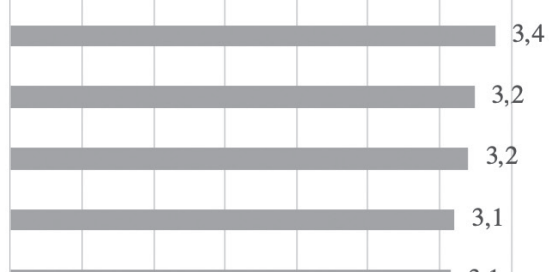

,
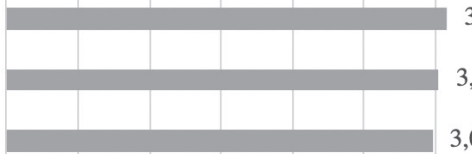

3,0
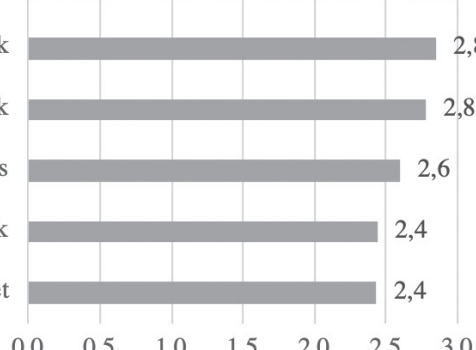

2,4

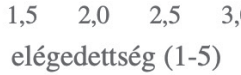

10. ábra Mennyire elégedett az alábbi települési tényezőkkel (1-5)? Forrás: saját kutatás

Figure 10 How satisfied are you with the following settlement factors (1-5)? Source: own research 
amelyek ily módon az önkormányzati fejlesztések célterületei lehetnének. Elégedetlenek a megkérdezettek a magas ingatlanárakkal is, bár erre az önkormányzatnak kevés ráhatása van. Esetleg az önkormányzat a szociális bérlakásszektor fejlesztésével javíthatna a helyzeten. A szentesiek elégedetlenek továbbá a helyi tömegközlekedéssel, a munkalehetôségekkel és az egészségügyi ellátásokkal és szolgáltatásokkal. Ezek közül az elsőre és az utolsóra az önkormányzat közvetlenül hatást gyakorolhat, a munkalehetőségekre (az állami szféra leépítése miatt) csak közvetve, például munkahelyteremtő beruházások ösztönzése által.

A következő kérdés arra vonatkozott, hogy milyen forrásokból tájékozódik a lakosság a szentesi és környékbeli hírekröl, eseményekröl. A választási lehetőségek között konkrét szentesi intézmények (könyvtár, múvelődési ház), az önkormányzat által támogatott médiumok valamint vállalkozási alapon múködtetett (nyomtatott és online média) kommunikációs csatornák is szerepeltek: összességében 20 lehetőséget kínáltunk fel. A mintába került szentesiek többsége a Szentes Mozaikot $(72,3 \%)$ használja erre a célra, ezt követi a Szentesi Gyors (minden második válaszadó, 56,7\% említette) és nagyon domináns a kisvárosban a személyes kapcsolatok szerepe (45,9\%: szájhagyomány, család, barát, ismerős hírforrás). Jelentôs információforrásnak számít a Szentesi Élet $(38,1 \%)$ és a közterületre kihelyezett plakátok, hirdetőtáblák $(28,5 \%)$. A város által múködtetett Szentes TV az 5. (35,7\%), a hivatalos honlap (szentes.hu) a 7. helyen (27,9\%) végzett e rangsorban.Érdekes eredmény, hogy még a könyvtárat $(9,3 \%)$ és a múvelődési házat $(9,1 \%)$ is többen használják, mint a szentes.lap.hu honlapot.

Lakóhelyválasztás szempontjából meghatározó az adott település oktatási kínálata és az intézmények színvonala. A kérdőívben megkérdeztük, hogy melyik szentesi oktatási intézményt tartják a „legerősebbnek” az általános iskolák közül, valamint a gimnáziumok és szakközépiskolák közül. Az általános iskolák közül egyértelmúen a Koszta József Általános Iskolát (40,9\%), majd a Kiss Bálint Református Általános Iskolát (28\%) és a Szent Erzsébet Általános Iskola és Óvodát $(17,1 \%)$ tartják a legjobbnak. A középiskolák közül kiugróan sok szavazatot kapott a Horváth Mihály Gimnázium (64,3\%), amelyet a Boros Sámuel Szakgimnázium és Szakközépiskola (22,8\%), valamint a Zsoldos Ferenc Szakgimnázium és Szakközépiskola $(6,6 \%)$ követ.

Két zárt kérdéssel szerettük volna feltárni, hogy a lakosság szerint milyen iparág, illetve milyen vendéglátó egység hiányzik Szentesről. Leginkább a szórakoztatóipart (21,7\%), az informatikát $(13,5 \%)$, a ruhaipart $(13,5 \%)$ és a gépipart $(11,7 \%)$ hiányolták a válaszadók. A vendéglátó egységek és szálláshely-szolgáltatásokon belül a válaszadók többsége több zenés szórakozóhelyet $(42,5 \%)$, hotelt $(11,6 \%)$, tejbárt $(10,4 \%)$ és gyorséttermet $(9,8 \%)$ szeretne.

A lakossági kérdőív az alábbi 4 nyílt kérdést is tartalmazta:

- Mi jut eszébe először Szentes nevének hallatán? Kérem, nevezzen meg 3 dolgot!

- Mivel érvelne egy jövőbeni lakosnak, véleménye szerint miért jó Szentesen élni?

- Milyen konkrét látnivalókat, rendezvényeket, fesztiválokat ajánlana Szentesen egy turistának? Kérjük, hogy a 3 legfontosabbat sorolja fel!

- Milyen fejlesztéseket javasolna Szentesen?

Mivel e kérdések többségére akár három választ is adhattak a megkérdezettek, ezért ezeknél a kérdéseknél a válaszok gyakorisága akár háromszorosa is lehet a minta elemszámának (527 fő). A fenti négy nyílt kérdés kategóriáit, valamint ezek előfordulási gyakoriságát (\%) a 4. táblázat foglalja össze.

Mivel a településnek a lakók által kívánt fejlesztése növeli a helyiek elégedettségét, ezért az 5. táblázatban részletesebben is bemutatjuk, hogy milyen válaszok érkeztek arra a kérdésre, hogy milyen fejlesztéseket javasolnának. 
A nyílt kérdésekre adott válaszok kategóriái (db említés, \%-os megoszlás) Categories of answers to open questions (No. quotes, \% distribution)

\begin{tabular}{|c|c|c|c|}
\hline $\begin{array}{c}\text { Mi jut eszébe } \\
\text { először } \\
\text { Szentes } \\
\text { nevének } \\
\text { hallatán? }\end{array}$ & $\begin{array}{c}\text { Mivel érvelne } \\
\text { egy jövoobeni } \\
\text { lakosnak, véleménye } \\
\text { szerint miért } \\
\text { jó Szentesen élni? }\end{array}$ & $\begin{array}{c}\text { Milyen konkrét látnivalókat, } \\
\text { rendezvényeket, } \\
\text { fesztiválokat ajánlana } \\
\text { Szentesen egy turistának? }\end{array}$ & $\begin{array}{l}\text { Milyen fejlesztéseket } \\
\text { javasolna Szentesen? }\end{array}$ \\
\hline \multicolumn{4}{|c|}{ a válaszok száma } \\
\hline$n=1461$ & $\mathrm{n}=702$ & $n=1348$ & $\mathbf{n}=907$ \\
\hline $\begin{array}{l}\text { 1. } 42 \% \\
\text { települési } \\
\text { adottságok, } \\
\text { jellemzók } \\
\text { 2. } 19 \% \\
\text { természeti } \\
\text { adottság } \\
\text { 3. } 17 \% \text { család, } \\
\text { barátok } \\
\text { 4. } 13 \% \\
\text { munkahely, } \\
\text { gazdaság }\end{array}$ & $\begin{array}{l}\text { 1. } 25 \% \text { nyugodt } \\
2.17 \% \text { élhető } \\
3.8 \% \text { csendes } \\
4.8 \% \text { szép }\end{array}$ & $\begin{array}{l}\text { 1. } 34 \% \text { rendezvények, } \\
\text { események } \\
\text { 2. } 16 \% \text { kulturális vonzerók, } \\
\text { események } \\
\text { 3. } 15 \% \text { városi séta, épületek, } \\
\text { piac, infrastruktúra } \\
\text { 4. } 13 \% \text { liget, fürdő, gyógy- } \\
\text { fürdő } \\
\text { 5. } 11 \% \text { természet, természeti } \\
\text { vonzerô (Tisza, Kurca part) } \\
\text { 6. } 7 \% \text { aktív turizmus, sport, } \\
\text { vízilabda, uszoda }\end{array}$ & $\begin{array}{l}\text { 1. } 21 \% \text { közlekedés } \\
\text { 2. } 10 \% \text { kultúra, } \\
\text { kikapcsolódás (nem } \\
\text { csak fiataloknak) } \\
\text { 3. } 9 \% \text { munkahelyteremtés } \\
\text { 4. } 9 \% \text { szórakozás, } \\
\text { fiatalok kikapcsolódási } \\
\text { lehetóségek } \\
\text { 5. } 7 \% \text { szállodaépítés } \\
\text { / strand } \\
\text { 6. } 6 \% \text { egészségügy } \\
\text { 7. } 6 \% \text { egyéb / jó példák }\end{array}$ \\
\hline \multicolumn{4}{|c|}{$\begin{array}{l}\text { A válaszok legfeljebb } 5 \% \text {-ban fordultak elő: } \\
\text { negatív gondolatok, egyéb }\end{array}$} \\
\hline & $\begin{array}{l}\text { családbarát } \\
\text { kisváros } \\
\text { tiszta / rendezett } \\
\text { természeti adottságok } \\
\text { biztonságos } \\
\text { barátságos } \\
\text { sport } \\
\text { munkahely } \\
\text { békés } \\
\text { emberek } \\
\text { elhelyezkedés } \\
\text { kultúra / látnivaló } \\
\text { olcsó } \\
\text { fejlő́dó } \\
\text { hangulatos }\end{array}$ & & $\begin{array}{l}\text { oktatás } \\
\text { közterület } \\
\text { öko } \\
\text { játszóterek, gyermekek } \\
\text { kikapcsolódási } \\
\text { lehetóśségei } \\
\text { vendéglátó-helyek } \\
\text { / vásárlás } \\
\text { termálvíz } \\
\text { sport } \\
\text { ingatlan-hasznosítás } \\
\text { mezógazdaság } \\
\text { / élelmiszeripar } \\
\text { Kurca patak } \\
\text { Tisza }\end{array}$ \\
\hline
\end{tabular}

Forrás: saját kutatás

Source: own reserach

Említettük, hogy mintánkban a 19-64 éves korosztály felülreprezentált volt, ami kimutatható a fejlesztési irányokra vonatkozó válaszokban is. Feltételezhetően a városvezetés kifejezetten ennek a rétegnek Szentessel, mint lakó- és munkahellyel való elégedettségét szeretné növelni, valamint a településről való elvándorlást igyekszik csökkenteni.

\section{Kapcsolatvizsgálatok}

A rangkorrelációs kapcsolatvizsgálatok az életminőség szempontjából több érdekes eredményt hoztak (az asszociációs, illetve vegyes kapcsolatokról ez nem mondható el). E fejezetben ezeket ismertetjük, a 6. táblázatban összefoglalt eredmények alapján. 
Milyen fejlesztéseket javasolna Szentesen? - kategóriák

What area of developments would you suggest in Szentes?

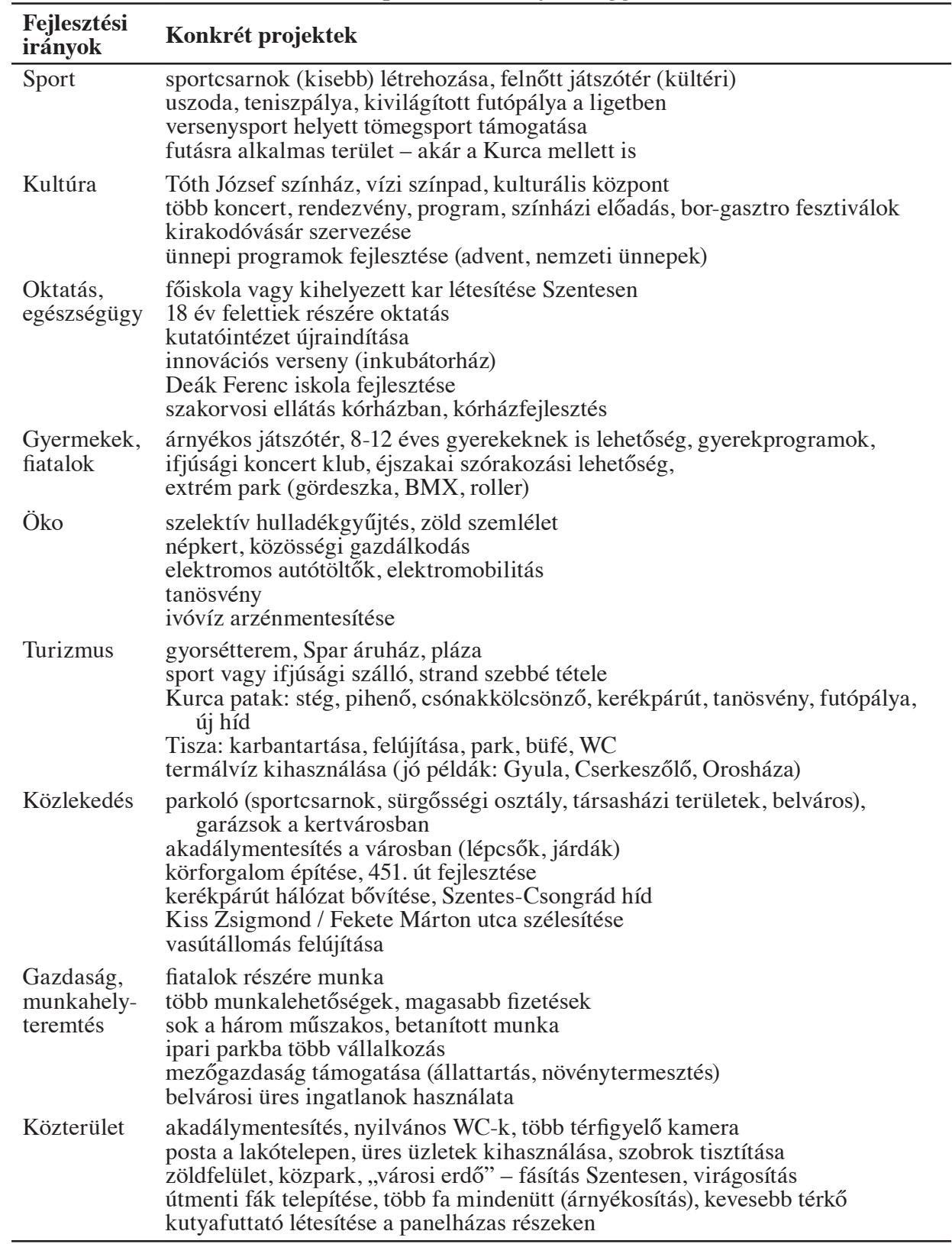

Forrás: saját kutatás

Source: own reserach 


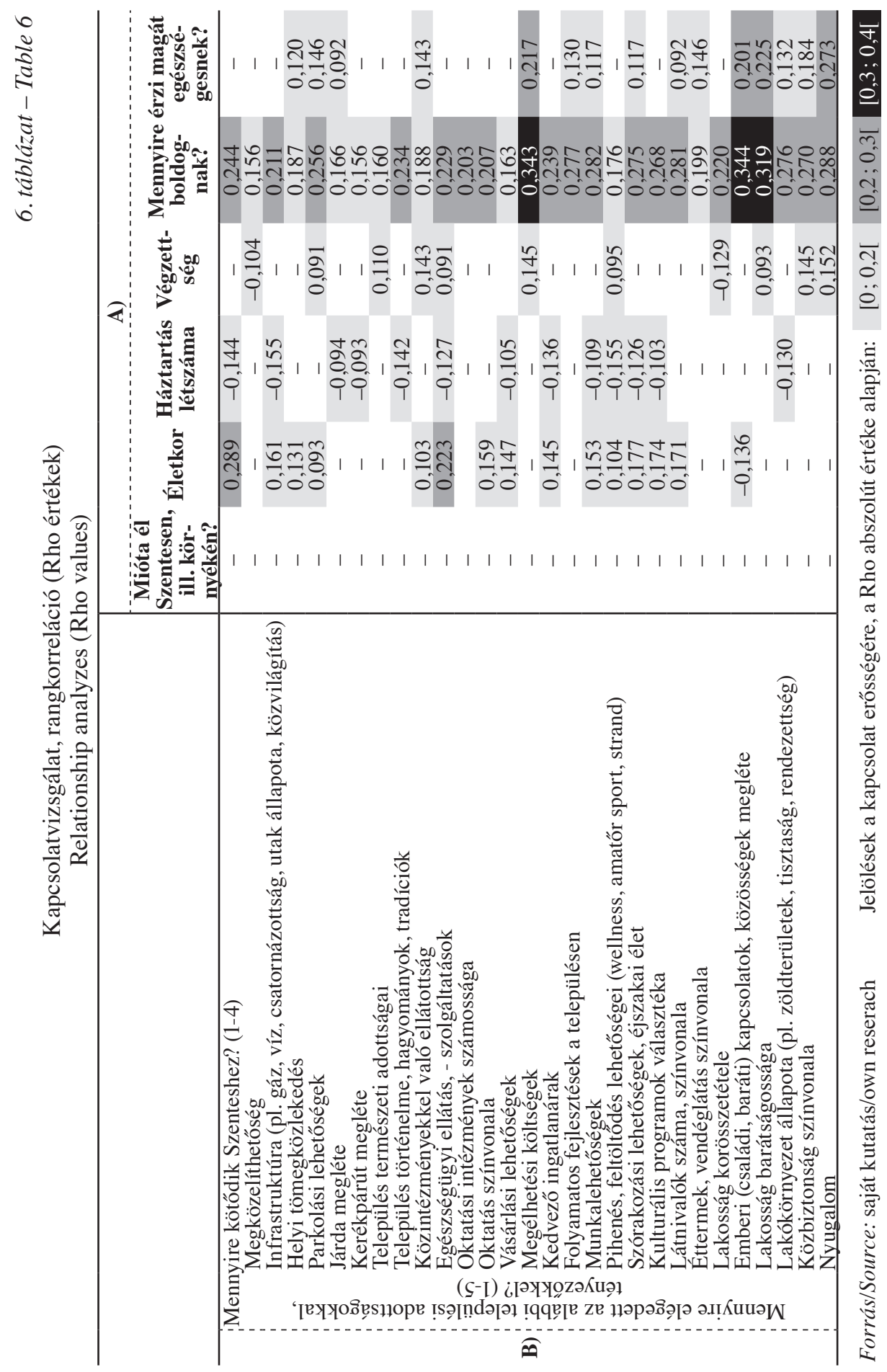


Az, hogy valaki mióta él Szentesen, nem áll szignifikáns kapcsolatban sem azzal, hogy mennyire kötődik a településhez, sem a felsorolt 28 települési jellemzővel való elégedettséggel. Ezzel szemben az, hogy valaki mennyire érzi magát boldognak, szignifikáns kapcsolatban áll az összes vizsgált mutatóval: azzal is, hogy mennyire kötődik a településhez és azzal is, hogy mennyire elégedett a felsorolt települési jellemzőkkel. Elmondhatjuk, hogy minél boldogabb valaki, annál inkább kötődik a településhez és annál elégedettebb a települési jellemzókkel.

A lakosok boldogságérzete leginkább azzal áll kapcsolatban, hogy mennyire elégedett az illetố a megélhetési költségekkel, az emberi (családi, baráti) kapcsolatok, közösségek meglétével és a lakosság barátságosságával. A Szenteshez való kötődés és a településsel való elégedettség leginkább a lakosok boldogságérzetével, majd az életkorral, ezt követôen pedig az egészségi állapottal magyarázható. Legkevésbé magyarázható a háztartás létszámával és a végzettséggel és egyáltalán nem bír befolyással az elégedettségre és kötődésre az, hogy valaki mióta él Szentesen.

A lakosok életkora kapcsán a szignifikáns kapcsolatok iránya - egy kivételével - pozitív, azaz minél idősebb valaki, annál elégedettebb az, adott városi jellemzôvel. A kivételt az emberi (családi, baráti) kapcsolatok, közösségek meglétével való elégedettség jelenti, azaz minél idősebb valakik, annál elégedetlenebb az emberi kapcsolatokkal. Ez a jelenség az idősebb korosztály elmagányosodásának jelenségével magyarázható. Az életkor a legerősebben azt befolyásolja, hogy az illető mennyire kötődik Szenteshez. Minél idősebb, annál inkább kötödik a településhez. Az életkor növekedése és az egészségügyi ellátásokkal, szolgáltatásokkal való elégedettség között is pozitív irányú a kapcsolat előjele, azaz e szolgáltatásokat feltehetően többször igénybe vevő idősebbek elégedettebbek ezzel a rendszerrel.

A háztartás létszáma esetében a szignifikáns kapcsolatok mindegyike negatív irányú, azaz minél több főból áll a háztartás, annál kevésbé kötődnek Szenteshez és annál elégedetlenebbek a településsel. A minta kb. 13\%-át nyugdíjasok adták, akik tipikusan egyedül élnek. Az előző megállapításunk úgy is megfogalmazható, hogy minél kevesebb fóból áll a háztartás, annál inkább kötődnek Szenteshez és annál elégedettebbek a településsel. Ez összhangban van azzal, miszerint minél idősebb valaki, annál inkább kötődik a településhez és annál elégedettebb többek között az egészségügyi ellátásokkal is.

Az iskolai végzettség esetében a szignifikáns kapcsolatokat vizsgálva elmondható, hogy pozitív irányú a kapcsolat, vagyis Szentesen a magasabb végzettségúek elégedettebbek, az alacsonyabb végzettségúek pedig elégedetlenebbek a várossal. Ez vonatkozik a város nyújtotta a parkolási lehetőségekre, a település természeti adottságaira, a közintézményekkel való ellátottságra, az egészségügyi ellátásra, a megélhetési költségekre, a pihenés és feltöltődés lehetóségeire, a közbiztonság színvonalára és a nyugalomra. A településen a magasabb végzettségúek elégedetlenebbek, az alacsonyabb végzettségúek elégedettebbek (negatív irányú a kapcsolat) a megközelíthetőséggel és a lakosság korösszetételével. Általában elmondhatjuk, hogy minél egészségesebbnek tartja magát valaki, annál elégedettebb a településsel.

\section{Összefoglalás}

A kérdőíves kutatás sok kapcsolódási pontra rávilágított. Bár egyik kutatási kérdésünkkel kapcsolatosan az volt az előzetes feltevésünk, hogy minél több éve él valaki Szentesen, annál elégedettebb a településsel, nem sikerült kimutatni szignifikáns kapcsolatot a települési tényezők egyikével sem. Az életkor, a háztartás létszáma, a végzettség, boldogság, 
egészség mindegyike szignifikáns kapcsolatban van bizonyos települési tényezőkkel. Az egyik legérdekesebb kapcsolat az emberi attitűddel magyarázható. Ez alapján kijelenthetjük, hogy akiknek szorosak a családi vagy baráti kapcsolatai és érzi a közösség erejét, azok boldogabbnak érzik magukat és a lakosságot is barátságosabbnak látják, valamint a megélhetési költségeikkel is elégedettebbek.

Második kutatási kérdésünk a helyiek által vágyott fejlesztésekre vonatkozott. A szentesiek a következő területeken szeretnének érdemi fejlesztéseket látni: közlekedés, kultúra és kikapcsolódás (mind a fiatalok, mind a 40 év felettiek részére), új munkahelyek és munkalehetőségek teremtése, szállodaépítés, a strand felújítása (gyógyvízzé minősítés), egészségügy (főleg a kórházi ellátás), oktatás (akár kihelyezett főiskolai/egyetemi képzés és felsőfokú szakképzés is), játszóterek és kikapcsolódási helyek.

Ami Szentes kapcsán sokszor hangsúlyozott elöny (nyugodt, csendes város), az egyben hátrány is lehet (unalmas, elöregedő). A helyi lakosok igénylik a színvonalas kulturális programokat, rendezvényeket egész évben. Legtöbben a szórakoztató-, informatikai- és ruhaipart hiányolják. Turisztikai szempontból a szórakozóhelyeket, szálláslehetőségeket és a Tisza és Kurca minél jobb kihasználását javasolják.

Tanulmányunk eredményei rámutattak arra, hogy a földrajzi, valamint gazdasági felmérések és elemzések segítségével jól feltárhatók a településhierarchia különböző szintjein álló települések - jelen esetben a kisvárosok - lakosságának életminőségét és boldogságát alapvetően meghatározó tényezők.

LŐRINCZ KATALIN

PE Turizmus Intézeti Tanszék, Veszprém

lorincz.katalin@gtk.uni-pannon.hu

KÖVÁRI EDIT MÁRIA

PE Szervezési és Vezetési Intézeti Tanszék, Veszprém

kovari.edit@gtk.uni-pannon.hu

BANÁSZ ZsUZSANNA

PE Kvantitatív Módszerek Intézeti Tanszék, Veszprém

banasz.zsuzsanna@gtk.uni-pannon.hu

\section{IRODALOM}

BANÁszZs. 2019: Hazánk közbiztonsága nemzetközi összehasonlításban. - Hadtudomány 29. 1-2.pp. 112-120. BODOR Á.-GRÜNHUT Z.-HoRECZKI R. 2017: Városi bizalmatlanság, vidéki bizalom. Esetleg fordítva? - A bizalom és a településtípus összefüggései Európában. - Területi Statisztika 57. 4. pp. 406-421.

DövÉNYI Z. 2007: A belföldi vándormozgalom strukturális és területi sajátosságai Magyarországon. - Demográfia, 50. 4. pp. 335-359.

DuSEK T. 2015: A lakókörnyezeti biztonságérzet településtípusok szerinti különbsége Magyarországon. - KözépEurópai Közlemények 8. 3. pp. 101-109.

EGEDY T. 2009: Városrehabilitáció és életminőség. Elmélet-Módszer-Gyakorlat. 64. MTA Földrajztudományi Kutatóintézet, Budapest. 152 p.

ENyEdi Gy. 2000: Globalizáció és a magyar területi fejlődés. - Tér és Társadalom. 14. 1. pp. 1-10.

ENYEDI Gy. 2003: Városi világ - Városfejlődés a globalizáció korában. - Habilitációs Előadások. PTE. Pécs.

ENYEDI Gy.-HoRváth Gy (szerk.) 2002: Táj, település, régió. - MTA Társadalomkutató Központ, Kossuth Kiadó, Budapest. 511 p.

Everitt J. C.-Gill A. M. 1993: The Social Geography of Small Towns. - In: Bourne, L. S. - Ley, D. F. (szerk.): The Changing Social Geography of Canadian Cities. pp. 252-264.

FARAGÓ L. 2007: Térstruktúra: térideák és megvalósításuk a településhálózat-fejlesztésben. - Tér és Társadalom 21. 4. pp. 21-38. 
GaÁL Z.-Szabó L.-SzABó M.-Zilahy GY. 2019: Kreatív város -fenntartható vidék. - Comitatus 29. 231. pp. 47-65.

Hamdouch A. I.-Nyseth T.-Demaziere C.-Førde A.-Serrano J.-Aarsæther N. (szerk.) 2017: Creative Approaches to Planning and Local Development: Insights from Small and Medium-Sized Town in Europe. - Routledge, New York, London. 264 p.

IvONY É. 2017: Szubjektív életminőség és érzelmi jóllét Magyarországon a gazdasági válság előtt és azt követően, európai kitekintéssel. - Statisztikai Szemle 95. 10. pp. 997-1022.

Jeney L. 2013: Városföldrajz. In: JENEY L.-Kulcsár D.-TózSA I. (szerk.): Gazdaságföldrajzi tanulmányok közgazdászoknak. - BCE Gazdaságföldrajzi és Jövőkutatási Tanszék, Budapest, pp. 39-70.

HautZinger Z.-Hegedús J.-Klenner Z. 2014: A migráció elmélete. - Magyar Közszolgálati Egyetem. Budapest. $106 \mathrm{p}$

KÉKESI M.Z. 2007: A szubjektív életminőség térbeli vonatkozásai. - In: UTASI Á. (szerk.): Az életminőség feltételei. Múhelytanulmányok. MTA Politikai Tudományok Intézete, Budapest. pp. 72-83.

Kiss J. P.-BAJMÓcY P. 2001: Városi funkciójú központok és elméleti vonzáskörzeteik az Alföldön. - Tér és Társadalom 15. 1. pp. 65-89.

Kostanick H. L. (szerk.) 2019: Population And Migration Trends In Eastern Europe. - Routledge, New York. $246 \mathrm{p}$.

Központi Statisztikai Hivatal Népességtudományi Kutatóintézet 2019: Népesség-előreszámítások. https:// demografia.hu/hu/letoltes/tudastar/nepesseg-eloreszamitasok/nepesseg-eloreszamitas-2015.pdf

Központi Statisztikai Hivatal 2019: Magyarország közigazgatási helynévkönyve 2019. január 1. http://www. ksh.hu/docs/hun/hnk/hnk_2019.pdf

Központi Statisztikai Hivatal 2018: Éves településstatisztikai adatok 2017-es településszerkezetben. http:// statinfo.ksh.hu/Statinfo/themeSelector.jsp?lang=hu

Központi Statisztikai Hivatal 2020: Éves településstatisztikai adatok 2018-as településszerkezetben. http:// statinfo.ksh.hu/Statinfo/haViewer.jsp

Központi Statisztikai Hivatal 2015: Magyarország településállománya. Városok - Falvak. http://www.ksh.hu/ docs/hun/xftp/idoszaki/mo_telepuleshalozata/varosok_falvak.pdf

KwiateK-SoŁtys A.-Mainet H. 2014: Quality of life and attractiveness of small towns: A comparison of France and Poland. - Quaestiones Geographicae 33. 2. pp. 103-113.

LENGYEL I. 2010: A regionális versenyképességről. - Közgazdasági Szemle 47. 12. pp. 962-987.

LeNGYel I.-REChNitZer J. 2004: Regionális gazdaságtan. - Dialóg Campus, Budapest-Pécs. 391 p.

LőRincz K. 2016: Miért jó Kőszegen élni? - In: Miszlivetz, F. (szerk): Kisvárosok reneszánsza: A kőszegi példa: KRAFT II. Felsőbbfokú Tanulmányok Intézete, Savaria Kiadó, Szombathely. pp. 365-390.

LŐRINCZ K. 2019: Gyöngyös, mint lakóhely és úti cél megítélése a helyi lakosság körében. - In: VERES Z.-SASnÉ Grósz A.-LiSKA F. (szerk.): Ismerjük a vevoot? A vásárlás pszichológiája. Az Egyesület a Marketingoktatásért és Kutatásért XXV. Országos konferenciájának előadásai Veszprém, Magyarország: Pannon Egyetem pp. 502-515.-

LŐRINCZ K.-RAFFAY Á. 2017: Zirc turizmusfejlesztési koncepciója 2017-2020. https://zirc.hu/application/ files/7415/6862/8633/Zirc_turizmusfejlesztesi_koncepcioja_2017-2020_final.pdf

MolNÁR B. 2006: A magyarországi kis- és középvárosok globalizációs típusai. - Tér és Társadalom 20. 4. pp. 67-83.

Peters D. J. 2019: Community Resiliency in Declining Small Towns: Impact of Population Loss on Quality of Life over 20 Years. - Rural Sociology 84. 4. pp. 635-668.

PIRISI G. 2009: Differenciálódó kisvárosaink. - Földrajzi Közlemények 133. 3. pp. 313-325.

Poreisz V. 2014: A városi versenyképesség dimenziói kisvárosok esetén. - In: LuKovics M.-ZuTi B. (szerk.): A területi fejlődés dilemmái. SZTE Gazdaságtudományi Kar, Szeged, pp. 65-79.

RECHNITZER J. 2002: A városhálózat az átmenetben, a kilencvenes évek változási irányai. - Tér és Társadalom 16. 3. pp. $165-183$.

Smith I. 2017: Demographic Change in European Towns 2001-11: A Cross-National Multi-Level Analysis. - Journal of Economic and Social Geography Special Issue: Dossier: Small and Medium-Sized Towns in Europe 108. 4. pp. 424-437.

Szabó M.-Tóth-KAszÁs N.-JAKOBi Á.-BANÁsz Zs. 2019: Szakértői jelentés a KRAFT-index NagykanizsaMurafölde felméréséről. - Felsőbbfokú Tanulmányok Intézete (FTI), Institute of Advanced Studies (iASK), KRAFT Központ, Kőszeg. 105 p.

Szentes Város Integrált Településfejlesztési Stratégiája 2014

TEIR 2019: Összes nettó jövedelem egy lakosra (Ft), járási szintű térkép, 2017. https://www.teir.hu/idosoros-elemzo/

Wirtha P.-Elisb V.-Müllerad B.-Yamamotoc K. 2016: Peripheralisation of small towns in Germany and Japan - Dealing with economic decline and population loss. - Journal of Rural Studies 47. pp. 62-75. 